\title{
USULAN PENURUNAN TINGKAT KECACATAN PRODUK PELAT BAJA DENGAN METODE SIX SIGMA
}

\author{
Muhamad Bob Anthony \\ Program Studi Teknik Industri, Fakultas Teknik, Universitas Serang Raya \\ Email: tonipbmti@gmail.com
}

\begin{abstract}
Abstrak - Penelitian ini bertujuan untuk memaksimalkan penurunan tingkat kecacatan produk untuk menuju zero defect. Peneliti menggunakan metode six sigma melalui 5 tahap penyelesaian yaitu, define, measure, analyze, improve, dan control. Berdasarkan hasil penelitian dapat disimpulkan bahwa tingkat sigma dan nilai DPMO (Defect per Million Opportunities) dari perusahaan sebesar 3,47 dengan kemungkinan kerusakan sebesar 24.239 lembar untuk satu juta produksi. Setelah dilakukan analisa lebih jauh menggunakan diagram pareto didapati bahwa jenis cacat cutting fault transfer defect adalah yang paling banyak terjadi dengan prosentase kerusakan sebesar 43\%. Dan berdasarkan hasil analisis diagram tulang ikan dapat diketahui faktor utama penyebab kerusakan dalam proses produksi berasal dari faktor pekerja (manusia), diikuti oleh faktor mesin, material dan metode kerja. Usulan perbaikan yang dapat dilakukan oleh perusahaan diantaranya adalah melakukan pembaharuan terhadap metode-metode dan SOP (standard operating procedure) yang sudah ada serta dilakukannya pengawasan terhadap kinerja operator dan pengembangan pengetahuan serta merencanakan penjadwalan perawatan yang baik.
\end{abstract}

Kata kunci: Diagram Pareto, Diagram tulang ikan, DPMO, Six Sigma

\begin{abstract}
This study aims to maximize the decline in the level of product defects to lead to zero defects. Researchers use the six sigma method through 5 stages of completion, namely, define, measure, analyze, improve, and control. Based on the results of the study it can be concluded that the sigma level and the value of DPMO (Defect per Million Opportunities) of the company amounted to 3.47 with possible damage of 24,239 sheets for one million productions. After further analysis using the Pareto diagram, it found that the cutting fault transfer defect was the most common with a percentage of damage of $43 \%$. And based on the results of the analysis of fishbone diagrams, it can be seen that the main factors causing contamination in the production process come from the worker factor (human), followed by machine factors, material, and work methods. The proposed improvements that can be made by the company include updating existing methods and SOPS (standard operating procedures) and monitoring the operator's performance and developing knowledge and planning proper maintenance scheduling.
\end{abstract}

Keywords: DPMO, Fish bone diagram, Pareto diagram, Six Sigma

\section{PENDAHULUAN}

Persaingan industri yang ketat memacu setiap perusahaan industri manufaktur maupun jasa untuk memiliki keunggulan kompetitif yaitu dalam segi kualitas (quality), harga (cost), ketepatan waktu pengiriman (delivery time) dan fleksibilitas (flexibility). Keunggulan kompetitif tersebut dapat tercapai dengan melakukan perbaikan secara terus menerus (continuous improvement). Faktor kualitas produk merupakan faktor penting karena sebagai penentu tingkat kepuasan yang diperoleh konsumen (Ghanimata \& Kamal, 2012). Pandangan untuk selalu melakukan yang terbaik untuk konsumennya membuat perusahaan-perusahaan memunculkan terobosan-terobosan baru dalam meningkatkan kualitas produknya. Peningkatan kualitas manajemen industri sangat ditentukan oleh adanya unsur input, proses, output dan pengendalian produk sebelum produk tersebut digunakan konsumen. Adapun dalam pengendalian kualitas itu sendiri, banyak metode yang dikenal, tetapi dari sekian banyak metode tersebut belum mampu membuktikan performance-nya dalam masalah peningkatan kualitas secara dramatik menuju tingkat kecacatan nol (zero defect).

Salah satu metode yang sering dipakai dalam menurunkan tingkat kecacatan adalah metode six sigma. Six sigma merupakan suatu metode atau teknik pengendalian dan peningkatan kualitas dramatik yang merupakan terobosan baru dalam bidang manajemen kualitas (Gaspersz, 2001). Six sigma merupakan 
proses disiplin tinggi yang membantu mengembangkan dan mengantarkan produk mendekati sempurna. Six sigma adalah suatu visi peningkatan kualitas menuju target 3,4 kegagalan per sejuta kesempatan (DPMO) untuk setiap transaksi produk baik barang maupun jasa (Trihendradi, 2006). Penerapan six sigma secara konsisten mampu meningkatkan kualitas produk yang dihasilkan perusahaan (Banuelas, Antony, \& Brace, 2005; Goh, Low, Tsui, \& Xie, 2003; Kumar, Nowicki, Ramírez-Márquez, \& Verma, 2008; Pheng \& Hui, 2004; Rohimudin, Dwiputra, \& Supriyadi, 2016)

Objek dalam penelitian ini merupakan perusahaan baja multinasional yang memproduksi slab \& plate berkualitas tinggi dengan standar internasional. Slab \& plate yang dihasilkan dipergunakan sebagai bahan pembuatan kapal, konstruksi bangunan serta berbagai jenis kebutuhan industri lainnya.

Berdasarkan data produksi perusahaan di tahun 2016, proses penipisan slab ke plate hingga proses finishing sering menimbulkan beberapa kecacatan pada produk jadi. Kecacatan-kecacatan ini disebabkan oleh banyak faktor sehingga harus ditelusuri faktor-faktor penyebabnya dan dilakukan pengembangan serta perbaikan secara terus menerus. Pada bulan september saja terdapat 3.329 lembar atau $9,24 \%$ cacat surface pada produk akhir dari total produksi 36.027 lembar. Di bulan Oktober dan November bahkan rata-rata kecacatan dalam produksi adalah sebesar $10,12 \%$ dan $10,09 \%$.

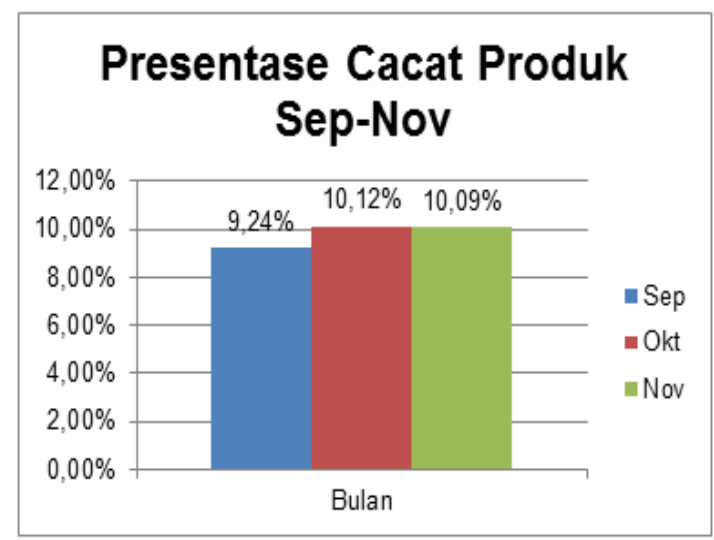

Gambar 1. Prosentase cacat produk september hingga november

Penelitian ini bertujuan untuk menganalisis terjadinya cacat yang terjadi pada proses slab \& plate dengan menggunakan metode six sigma. Hasil analisa ini bisa dimanfaatkan perusahaan dalam meminimalkan atau menghilangkan penyebab terjadinya cacat tersebut.

\section{METODE PENELITIAN}

Penelitian ini dilakukan terhadap produk pelat baja cacat yang diproduksi oleh perusahaan baja multinasional yang memproduksi slab \& plate berkualitas tinggi dengan standar internasional. Pengambilan data dilakukan dengan cara melihat data historis di Plate Rolling Department mulai bulan Januari hingga Desember 2016.

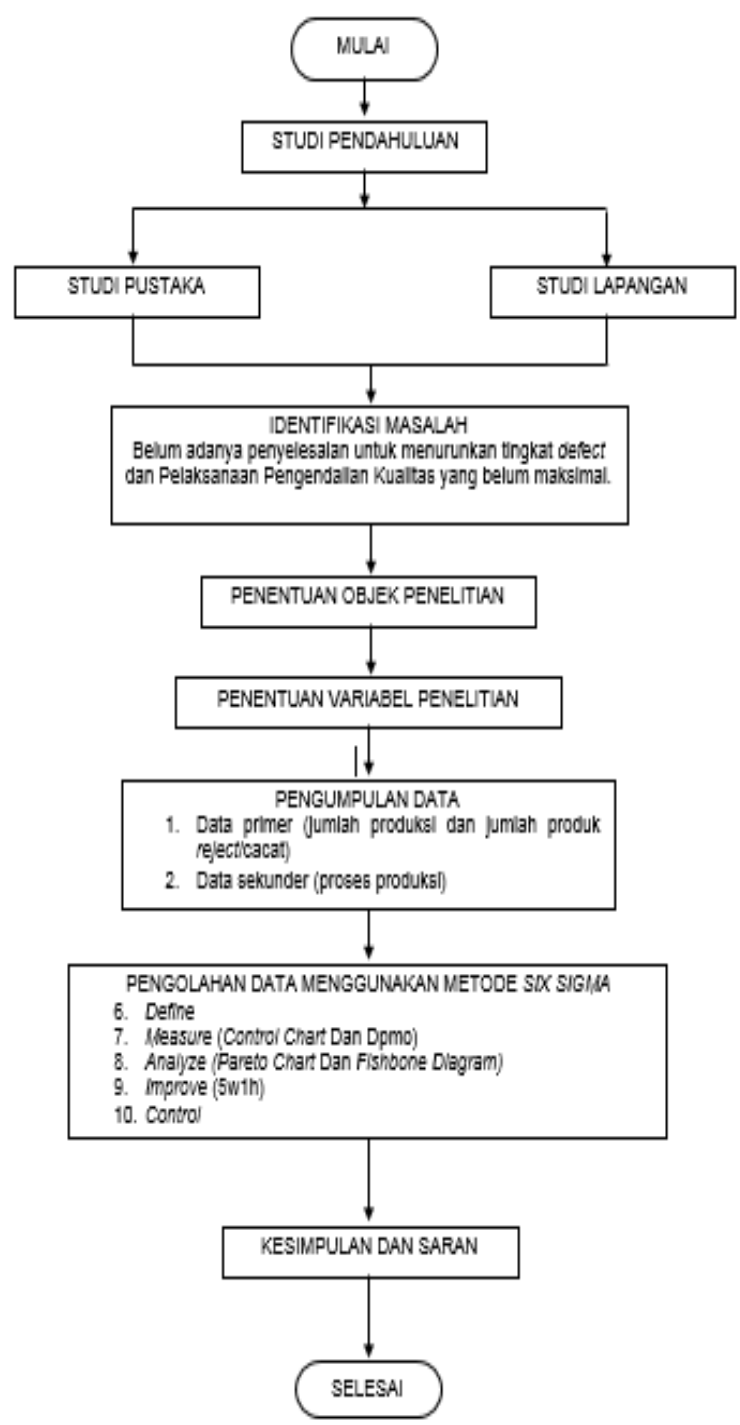

Gambar 2. Alur penelitian

Pada penelitian ini menggunakan metode six sigma melalui 5 tahap penyelesaian yaitu, define, measure, analyze, improve dan control. Define merupakan langkah pengoperasian pertama dalam peningkatan kualitas berdasarkan Six Sigma. Dalam langkah define, masalah (cacat produk) mulai diidentifikasi dan di kelompokan (Breyfogle, 2003).

Measure merupakan pengukuran variabel proses melalui pemeriksaan kualitas data, studi 
repeatability and reproducibility (R\&R), dan membahas stabilitas proses (Ranjan Senapati, 2004). Pada tahap ini akan dilakukan pengukuran nilai sigma saat ini sebagai dasar penentuan tujuan peningkatan nilai sigma.

Analyze adalah langkah selanjutnya yang dilakukan untuk mengidentifikasi akar penyebab masalah berdasarkan pada analisa data yang ada dengan menggunakan diagram pareto dan diagram tulang ikan (fishbone diagram) (Breyfogle, 2003).

Improve yaitu tahap dilakukannya pengujian dari solusi atau penyelesaian masalah serta rekomendasi usulan perbaikan yang di dilakukan untuk mengeliminasi penyebab masalah yang ada dengan menggunakan metode $5 \mathrm{~W}+1 \mathrm{H}$ (what, when, where, which, who, dan how) (Breyfogle, 2003).

Control adalah tahap yang berisikan tentang ide atau cara pengontrolan berdasarkan dari penerapan perbaikan yang dilakukan. Control dilakukan untuk menyakinkan bahwa hasil-hasil yang diinginkan sedang dalam proses pencapaian (Breyfogle, 2003).

\section{HASIL DAN PEMBAHASAN \\ Define}

Tahap pertama dalam DMAIC adalah Define. Dalam tahap ini dilakukan dengan pendefinisian masalah-masalah standar kualitas atau mendefinisikan penyebab-penyebab cacat (defect) yang menjadi penyebab paling potensial.

Tabel 1. Data jumlah produksi dan cacat produk tahun 2016

\begin{tabular}{|l|c|c|}
\hline \multicolumn{1}{|c|}{ Bulan } & $\begin{array}{c}\text { Jumlah Produksi } \\
\text { (Lembar) }\end{array}$ & $\begin{array}{c}\text { Jumlah Produk cacat } \\
\text { (Lembar) }\end{array}$ \\
\hline Januari & 25705 & 2403 \\
\hline Februari & 14509 & 1358 \\
\hline Maret & 29457 & 2757 \\
\hline April & 44424 & 4513 \\
\hline Mei & 43231 & 4085 \\
\hline Juni & 27567 & 2627 \\
\hline Juli & 22918 & 2307 \\
\hline Agustus & 30998 & 3180 \\
\hline September & 36027 & 3399 \\
\hline Oktober & 36253 & 3754 \\
\hline November & 33294 & 3453 \\
\hline Desember & 49690 & 5209 \\
\hline Total & 394073 & 39045 \\
\hline
\end{tabular}

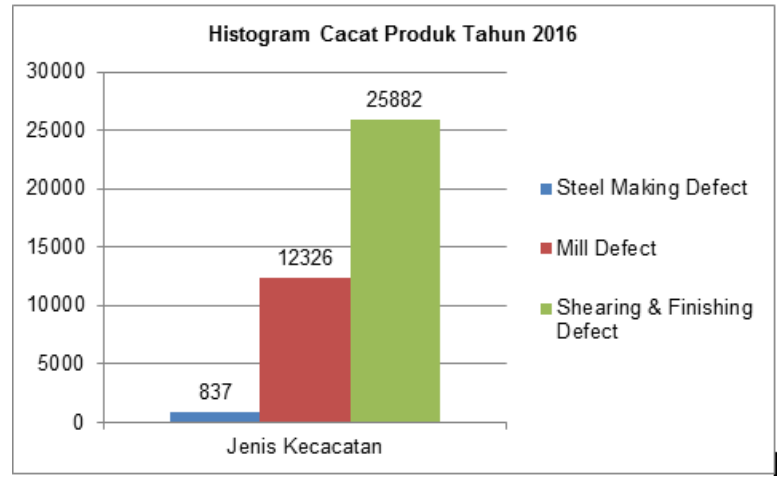

Gambar 3. Histogram kecacatan produk tahun 2016

Dari gambar 3, dapat diketahui jenis kerusakan yang paling banyak terjadi adalah area shearing \& finishing dengan jumlah sebanyak 25882 lembar. Setelah itu area mill sebanyak 12326 lembar dan area Steel Making sebanyak 837 lembar.

Dari data diatas dapat ditarik kesimpulan bahwa dari tempat berasalnya defect didapatkan 2 tempat yang cukup tinggi yaitu area mill dan area shearing \& finishing. Untuk itu dalam penelitian ini difokuskan pada 2 tempat terjadinya cacat tersebut, karena di area ini produk paling banyak menghasilkan cacat.

Pada area mill dan shearing \& finishing terdapat 3 defect utama yang terjadi yaitu rolling surface defect, cutting fault \& transfer defect dan marking revision. Berikut penjelasaan mengenai defect-defect tersebut.

a. Rolling surface defect

Rolling surface defect merupakan kecacatan produk yang terjadi karena adanya benda/material asing yang ada pada permukaan produk baik berasal dari dalam maupun luar material. Kecacatan ini terjadi dimulai dari proses pemanasan hingga penipisan dari slab ke plate (Gambar 4).

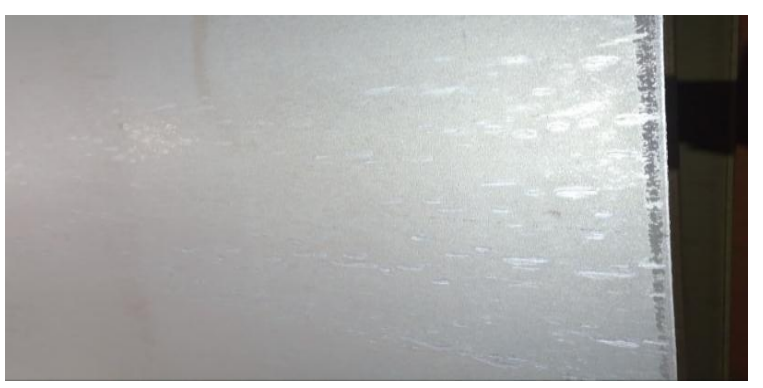

Gambar 4. Rolling surface defect

\section{b. Cutting fault \& transfer defect}

Kecacatan ini berasal dari area shearing \& finishing yaitu terjadinya ketidaksempurnaan pada sisi hasil pemotongan pelat dan munculnya cacat akibat material flow (proses perjalanan 
produk dari satu proses ke proses lainnya) (Gambar 5).

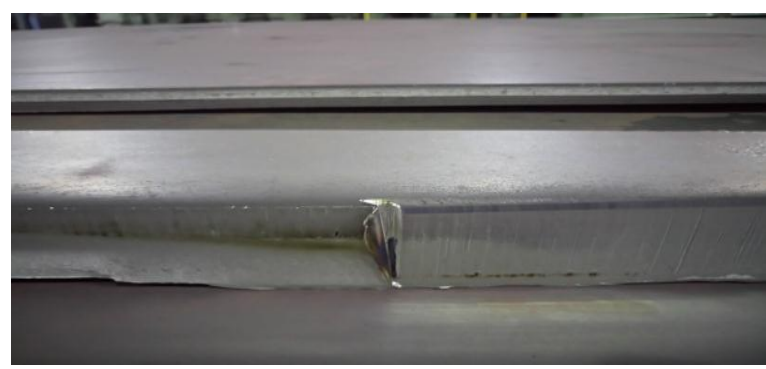

Gambar 5. Cutting fault \& transfer defect

\section{c. Marking revision}

Kecacatan ini berwujud pada kurang baiknya hasil penandaan identitas dari produk (Gambar 6).

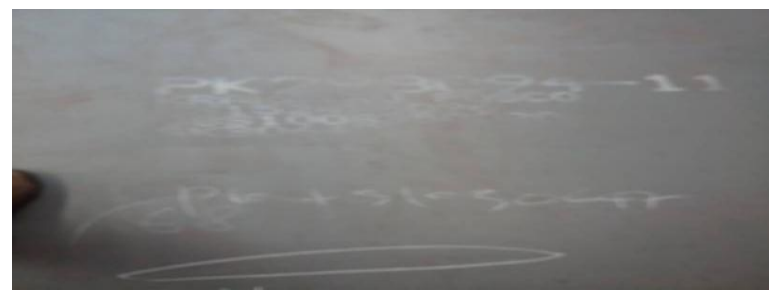

Gambar 6. Marking revision

\section{Measure}

Pada tahap kedua yaitu measure, pertama dilakukan identifikasi CTQ (critical to quality) dari cacat produk (Tabel 2). Kemudian dari hasil data yang telah diambil, dilakukan tahap pengukuran dan analisa melalui analisis diagram kontrol (control chart) untuk mengetahui apakah kecacatan produk masih dalam batas kendali atau tidak. Setelah itu dilakukan perhitungan DPMO dan nilai six sigma.

Tabel 2. CTQ produk pelat baja

\begin{tabular}{|c|c|c|}
\hline No. & Critiqal To Quality (CTQ) & Keterangan \\
\hline 1. & Rolling Surface Defect & $\begin{array}{l}\text { Kecacatan ini terjadi pada proses furnace } \\
\text { dan rolling dari slab ke pelat. Kondisi pelat } \\
\text { menjadi cacat akibat adanya benda asing } \\
\text { baik dari dalam maupun luar material. }\end{array}$ \\
\hline 2. & $\begin{array}{l}\text { Cutting Fault and Transfer } \\
\text { Defect (Machine) }\end{array}$ & $\begin{array}{l}\text { Kondisi dari kecacatan pelat ini adalah } \\
\text { adanya pemotongan yang tidak sempuma/ }\end{array}$ \\
\hline 3. & $\begin{array}{l}\text { Cutting Fault and Transfer } \\
\text { Defect (Gas) }\end{array}$ & $\begin{array}{l}\text { kurang baik sehingga menyisakan excess } \\
\text { material pada hasil pemotongan. }\end{array}$ \\
\hline 4. & Marking Revision & $\begin{array}{l}\text { Kondisi dimana tanda/identitas pada pelat } \\
\text { tidaklengkap/jelas. }\end{array}$ \\
\hline
\end{tabular}

Tabel 3. Data produksi dan produk cacat tahun 2016

\begin{tabular}{|c|c|c|c|c|c|c|}
\hline \multirow[b]{2}{*}{ Bulan } & \multirow[b]{2}{*}{ 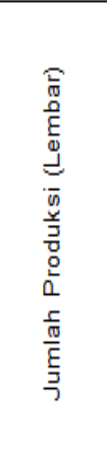 } & \multicolumn{3}{|c|}{ Jenis Cacat } & \multirow[b]{2}{*}{ 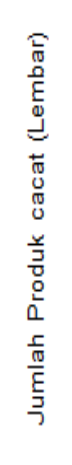 } & \multirow[b]{2}{*}{ 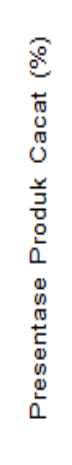 } \\
\hline & & 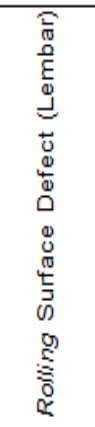 & 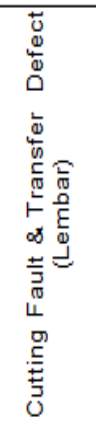 & 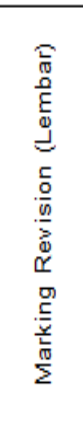 & & \\
\hline 1 & 25705 & 798 & 1099 & 476 & 2373 & 9,23 \\
\hline 2 & 14509 & 596 & 597 & 148 & 1341 & 9,24 \\
\hline 3 & 29457 & 989 & 1416 & 326 & 2731 & 9,27 \\
\hline 4 & 44424 & 1464 & 2256 & 737 & 4457 & 10,03 \\
\hline 5 & 43231 & 1469 & 1496 & 1058 & 4023 & 9,31 \\
\hline 6 & 27567 & 1209 & 699 & 637 & 2545 & 9,23 \\
\hline 7 & 22918 & 719 & 910 & 609 & 2238 & 9,77 \\
\hline 8 & 30998 & 1138 & 1266 & 731 & 3135 & 10,11 \\
\hline 9 & 36027 & 696 & 1583 & 1050 & 3329 & 9,24 \\
\hline 10 & 36253 & 1063 & 1526 & 1079 & 3668 & 10,12 \\
\hline 11 & 33294 & 1016 & 1414 & 928 & 3358 & 10,09 \\
\hline 12 & 49690 & 1169 & 2218 & 1623 & 5010 & 10,08 \\
\hline Total & 394073 & 12326 & 16480 & 9402 & 38208 & \\
\hline Rata-rata & 32839,42 & 1027,17 & 1373,33 & 783,50 & 3184 & 9,64 \\
\hline
\end{tabular}

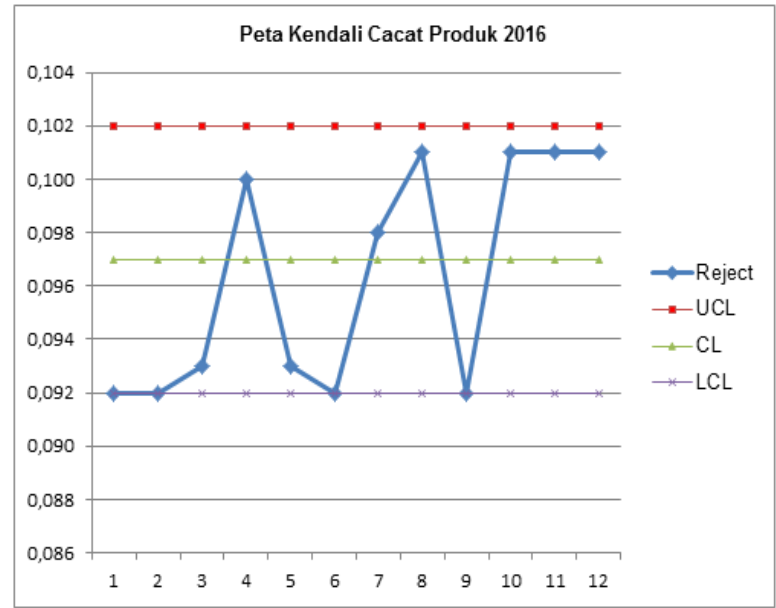

Gambar 7. Peta kendali p-chart kecacatan produk tahun 2016

Dari gambar 7 dapat dilihat bahwa semua titik berada di dalam batas kendali sehingga bisa ditarik kesimpulan bahwa proses terkendali. Walaupun dalam batas kendali, namun kecacatan pelat masing diatas batas dari target perusahaan hal ini menunjukkan bahwa pengendalian kualitas untuk produk jadi masih 
harus ditingkatkan.

Tabel 4. Data hasil perhitungan nilai DPMO dan nilai sigma tahun 2016

\begin{tabular}{|c|c|c|c|c|c|c|c|}
\hline Bulan & 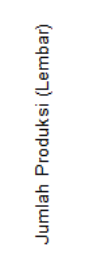 & 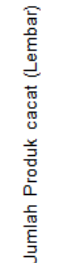 & 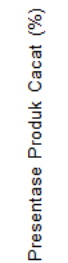 & गे & $\begin{array}{l}\circ \\
\vdots \\
0\end{array}$ & $\frac{0}{\sum_{0}^{2}}$ & $\begin{array}{l}\frac{\pi}{\xi} \\
\frac{\omega}{\omega} \\
\frac{\pi}{\bar{n}}\end{array}$ \\
\hline 1 & 25705 & 2373 & 9,23 & 0,092 & 0.023 & 23079,167 & 3,49 \\
\hline 2 & 14509 & 1341 & 9,24 & 0,092 & 0.023 & 23106,348 & 3,49 \\
\hline 3 & 29457 & 2731 & 9,27 & 0,093 & 0.023 & 23177,852 & 3,49 \\
\hline 4 & 44424 & 4457 & 10,03 & 0,100 & 0,025 & 25082,163 & 3,46 \\
\hline 5 & 43231 & 4023 & 9,31 & 0,093 & 0,023 & 23264,556 & 3,49 \\
\hline 6 & 27567 & 2545 & 9,23 & 0,092 & 0,023 & 23080,132 & 3,49 \\
\hline 7 & 22918 & 2238 & 9,77 & 0,098 & 0,024 & 24413,125 & 3,47 \\
\hline 8 & 30998 & 3135 & 10,11 & 0,101 & 0,025 & 25283,889 & 3,45 \\
\hline 9 & 36027 & 3329 & 9,24 & 0,092 & 0,023 & 23100,730 & 3,49 \\
\hline 10 & 36253 & 3668 & 10,12 & 0,101 & 0,025 & 25294,458 & 3,45 \\
\hline 11 & 33294 & 3358 & 10,09 & 0,101 & 0.025 & 25214,753 & 3,45 \\
\hline 12 & 49690 & 5010 & 10,08 & 0,101 & 0,025 & 25206,279 & 3,45 \\
\hline Total & 394073 & 38208 & 115,72 & 0,097 & 0,024 & 24239,2 & 3,47 \\
\hline Rata-rata & 32839,42 & 3184 & 9,64 & 0,096434 & 0.0241086 & 24108,6 & \\
\hline
\end{tabular}

Dari tabel 4 dapat terlihat bahwa nilai sigma pada tahun 2016 sebesar 3,47 dengan kemungkinan kerusakan sebesar 24.239 lembar untuk satu juta produksi. Hasil ini menunjukan bahwa nilai sigma masih harus ditingkatkan karena perusahaan merupakan perusahaan multinasional yang bersaing sehingga dengan meningkatkan nilai sigma ke tahun berikutnya dapat meningkatkan keuntungan perusahaan dan menurunkan tingkat kerugian yang diakibatkan oleh cacat produk.

\section{Analyze}

Pada tahap ini, hasil olahan data akan dianalisa untuk mencari faktor penyebab terjadinya kecacatan pada produk baja yang dihasilkan dengan diagram pareto (Gambar 8) dan diagram tulang ikan (Fishbone diagram).

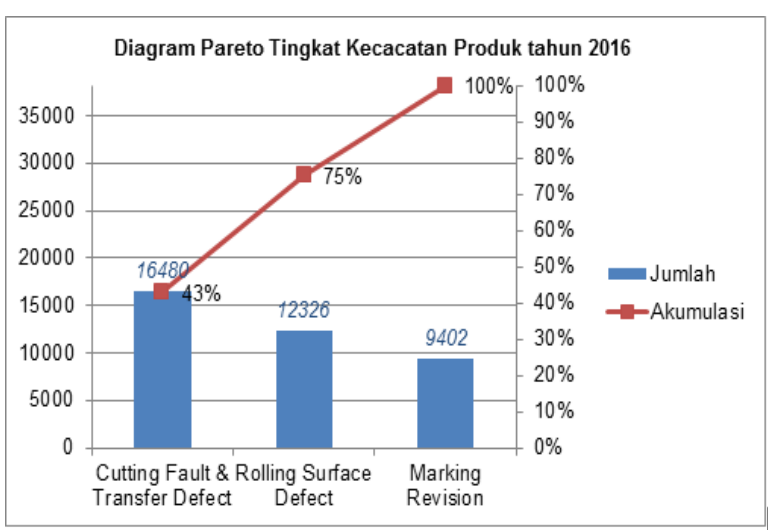

Gambar 8. Diagram pareto tingkat kecacatan produk tahun 2016
Dari diagram pareto di atas, dapat kita lihat bahwa kecacatan produk didominasi oleh cutting fault \& transfer defect sebesar 43\%, rolling surface defect sebesar $32 \%$ dan marking defect $25 \%$. Karena marking defect utamanya terjadi pada keadaan offline dan berkaitan dengan kecacatan lainnya. Dengan itu usulan perbaikan akan dilakukan dengan memfokuskan pada jenis penyebab kecacatan terbesar yaitu cutting fault \& transfer defect.

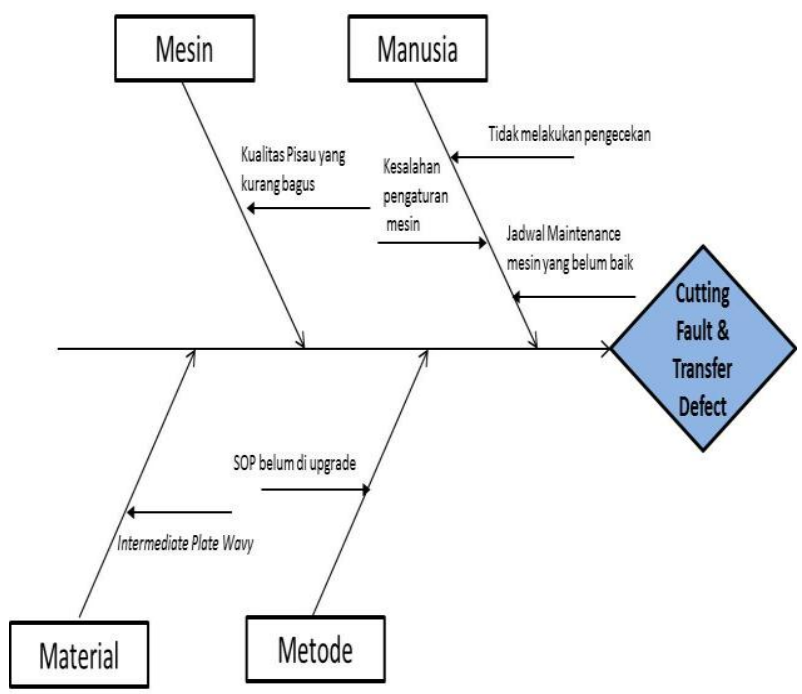

Gambar 9. Fishbone diagram penyebab cacat cutting fault \& transfer defect

Adapun gambar fishbone diagram penyebab cacat cutting fault \& transfer defect dapat diuraikan sebagai berikut :

1. Faktor manusia

- Operator tidak melakukan pemeriksaan secara terjadwal terhadap kualitas pisau yang dipakai untuk memotong produk.

- Operator salah dalam mengatur gap (celah) dari pisau sehingga terjadi excess material (kelebihan material).

- Operator tidak melakukan pemeriksaan atau pembersihan secara berkala terhadap roll table dan fasilitas flow material sehingga menyebabkan adanya benda asing yang menempel pada roll table dan fasilitas sehingga menyebabkan goresan pada permukaan produk.

- Pengaturan jadwal maintenance (perawatan) yang belum maksimal oleh planner.

2. Faktor mesin

- Pada faktor mesin, kualitas pisau yang kurang bagus menyebabkan hasil pemotongan yang tidak sempurna. 
3. Faktor material

- Intermediate Plate dalam keadaan bergelombang.

4. Faktor metode

- SOP (standard operating procedure) belum maksimal di upgrade (revisi) sehingga ada beberapa metode yang seharusnya sudah diubah tapi belum diubah.

\section{Improve}

Tahap selanjutnya dalam tahapan DMAIC adalah improve. Pada tahap ini, hasil analisa menggunakan diagram tulang ikan pada tahap sebelumnya dilakukan usulan perbaikan untuk mengurangi bahkan menghilangkan cacat yang terjadi pada produk menggunakan metode $5 \mathrm{~W}+1 \mathrm{H}$ (what, when, where, which, who, dan how) (Tabel 5).

Tabel 4.7. Usulan perbaikan cutting fault \& transfer defect dengan $5 \mathrm{~W}+1 \mathrm{H}$

\begin{tabular}{|c|c|c|c|c|c|c|c|c|}
\hline No. & $\begin{array}{c}\text { Faktor } \\
\text { Penyebab }\end{array}$ & Permasalahan & What & Why & Where & When & Who & How \\
\hline 1 & \multirow{2}{*}{$\begin{array}{c}\text { Faktor } \\
\text { Manusia }\end{array}$} & $\begin{array}{c}\text { Operator tidak } \\
\text { melakukan } \\
\text { pemeriksaan } \\
\text { secara terjadwal } \\
\text { terhadap kualitas } \\
\text { pisau yang dipakai } \\
\text { untuk memotong } \\
\text { pelat. }\end{array}$ & $\begin{array}{l}\text { Tidak melakukan } \\
\text { pemeriksaan secara } \\
\text { terjadwal terhadap } \\
\text { kualitas pisau }\end{array}$ & $\begin{array}{c}\text { Tidak ada } \\
\text { jadwal } \\
\text { pemeriksaan }\end{array}$ & $\begin{array}{l}\text { Mesin } \\
\text { Pemotongan }\end{array}$ & $\begin{array}{c}\text { Pada saat } \\
\text { pemotongan } \\
\text { produk }\end{array}$ & Operator & $\begin{array}{l}\text { Standar pisau untuk } \\
\text { pemotongan plate yaitu } \\
50.000 \mathrm{x} \text { potong. Untuk itu } \\
\text { dibuat Checklist dimana } \\
\text { setelah } 40.000 \mathrm{x} \\
\text { pemotongan dibuat } \\
\text { checksheet untuk } \\
\text { pemeriksaan hasil } \\
\text { pemotongan produk }\end{array}$ \\
\hline 2 & & $\begin{array}{c}\text { Operator salah } \\
\text { dalam mengatur } \\
\text { gap dari pisau } \\
\text { sehingga terjadi } \\
\text { excess material } \\
\text { berupa cutting chip } \\
\text { dan burr }\end{array}$ & $\begin{array}{l}\text { Salah dalam mengatur } \\
\text { gap dari pisau }\end{array}$ & $\begin{array}{c}\text { Operator } \\
\text { kurang teliti }\end{array}$ & $\begin{array}{c}\text { Mesin } \\
\text { Pemotongan }\end{array}$ & $\begin{array}{l}\text { Pada saat } \\
\text { pemotongan } \\
\text { produk }\end{array}$ & Operator & $\begin{array}{c}\text { Jika ada perpindahan } \\
\text { tebal pada saat } \\
\text { pemotongan produk, } \\
\text { operator mesin } \\
\text { pemotongan harus } \\
\text { mengecek hasil } \\
\text { pemotongan produk } \\
\text { pertama (Pasang kamera } \\
\text { di F/S dan M/S) }\end{array}$ \\
\hline No. & $\begin{array}{c}\text { Faktor } \\
\text { Penyebab }\end{array}$ & han masalahan & What & Why & Where & When & Who & How \\
\hline 3 & $\begin{array}{l}\text { Faktor } \\
\text { Manusia }\end{array}$ & $\begin{array}{c}\text { Operator tidak } \\
\text { melakukan } \\
\text { pemeriksaan atau } \\
\text { pembersihan } \\
\text { secara berkala } \\
\text { terhadap roll table } \\
\text { dan fasilitas flow } \\
\text { material sehingga } \\
\text { menyebabkan } \\
\text { adanya benda } \\
\text { asing yang } \\
\text { menempel pada } \\
\text { roll table dan } \\
\text { fasilitas dan } \\
\text { menyebebkan } \\
\text { goresan pada } \\
\text { permukaan pelat. }\end{array}$ & $\begin{array}{c}\text { Tidak melakukan } \\
\text { pemeriksaan atau } \\
\text { pembersihan secara } \\
\text { berkala terhadap roll } \\
\text { table dan fasilitas flow } \\
\text { material }\end{array}$ & $\begin{array}{l}\text { Lini produksi } \\
\text { padat }\end{array}$ & $\begin{array}{c}\text { Mesin } \\
\text { Pemotongan } \\
\text { dan area } \\
\text { flow material }\end{array}$ & $\begin{array}{l}\text { Pada saat } \\
\text { pemotongan } \\
\text { produk dan } \\
\text { proses flow } \\
\text { material }\end{array}$ & Operator & $\begin{array}{l}\text { Operator melakukan } \\
\text { pemeriksaan atau } \\
\text { pembersihan secara } \\
\text { berkala terhadap roll } \\
\text { table dan fasilitas flow } \\
\text { material minimal } 1 \mathrm{x} \\
\text { untuk } 1 \text { shift (pada saat } \\
\text { line tidak terlalu } \\
\text { padat/awal shift) dengan } \\
\text { mengisi Checksheet }\end{array}$ \\
\hline
\end{tabular}


Tabel 4.7. Usulan perbaikan cutting fault \& transfer defect dengan $5 \mathrm{~W}+1 \mathrm{H}$ (lanjutan)

\begin{tabular}{|c|c|c|c|c|c|c|c|c|}
\hline No. & $\begin{array}{c}\text { Faktor } \\
\text { Penyebab }\end{array}$ & Permasalahan & What & Why & Where & When & Who & How \\
\hline 4 & $\begin{array}{l}\text { Faktor } \\
\text { Manusia }\end{array}$ & $\begin{array}{c}\text { Pengaturan jadwal } \\
\text { maintenance yang } \\
\text { belum maksimal } \\
\text { oleh planner }\end{array}$ & $\begin{array}{l}\text { Pengaturan jadwal } \\
\text { maintenance yang } \\
\text { belum maksimal }\end{array}$ & $\begin{array}{c}\text { Waktu } \\
\text { produksi } \\
\text { yang padat } \\
\text { serta jadwal } \\
\text { maintenance } \\
\text { yang kadang } \\
\text { - kadang } \\
\text { berubah }\end{array}$ & $\begin{array}{c}\text { Mesin } \\
\text { Pemotongan }\end{array}$ & $\begin{array}{l}\text { Waktu } \\
\text { produksi }\end{array}$ & $\begin{array}{l}\text { Production } \\
\text { and } \\
\text { Maintenance } \\
\text { planner }\end{array}$ & $\begin{array}{c}\text { Pembuatan Jadwal } \\
\text { Produksi dan } \\
\text { Maintenance harus tepat, } \\
\text { untuk itu produksi harus } \\
\text { berjalan lancar dengan } \\
\text { adanya maintenance } \\
\text { yang teratur sehingga } \\
\text { tidak ada maintenance } \\
\text { dadakan. Planner harus } \\
\text { melakukan reschedule } \\
\text { yang tepat jika terjadi } \\
\text { masalah pada bagian } \\
\text { produksi }\end{array}$ \\
\hline 5 & $\begin{array}{l}\text { Faktor } \\
\text { Mesin }\end{array}$ & $\begin{array}{l}\text { Kualitas pisau yang } \\
\text { kurang bagus } \\
\text { menyebabkan hasil } \\
\text { coak ataupun } \\
\text { pemotongan yang } \\
\text { tidak sempurna. }\end{array}$ & $\begin{array}{l}\text { Hasil pemotongan } \\
\text { coak ataupun } \\
\text { pemotongan tidak } \\
\text { sempurna. }\end{array}$ & $\begin{array}{l}\text { Kualitas } \\
\text { pisau kurang } \\
\text { bagus }\end{array}$ & $\begin{array}{c}\text { Mesin } \\
\text { Pemotongan }\end{array}$ & $\begin{array}{l}\text { Pada saat } \\
\text { pemotongan } \\
\text { produk }\end{array}$ & $\begin{array}{l}\text { Material } \\
\text { Mgt. }\end{array}$ & $\begin{array}{l}\text { Melakukan pemeriksaan } \\
\text { terhadap kualitas pisau } \\
\text { yang akan digunakan }\end{array}$ \\
\hline No. & $\begin{array}{c}\text { Faktor } \\
\text { Penyebab }\end{array}$ & Permasalahan & What & Why & Where & When & Who & How \\
\hline 6 & $\begin{array}{l}\text { Faktor } \\
\text { Material }\end{array}$ & $\begin{array}{c}\text { Intermediate Plate } \\
\text { wavy }\end{array}$ & $\begin{array}{c}\text { Pelat tipis dengan } \\
\text { ketebalan < } 10 \mathrm{~mm} \\
\text { sering berbentuk } \\
\text { bergelombang } \\
\text { sehingga } \\
\text { menghasilkan } \\
\text { pemotongan yang } \\
\text { jelek. }\end{array}$ & $\begin{array}{l}\text { Proses } \\
\text { Leveling } \\
\text { yang tidak } \\
\text { sempurna }\end{array}$ & $\begin{array}{l}\text { Hot Leveller } \\
\text { dan Mesin } \\
\text { Pemotongan }\end{array}$ & $\begin{array}{l}\text { Proses } \\
\text { Leveling } \\
\text { dan } \\
\text { pemotongan }\end{array}$ & $\begin{array}{l}\text { Operator, } \\
\text { foreman, } \\
\text { engineer }\end{array}$ & $\begin{array}{c}\text { Dibutuhkan Improvement } \\
\text { dari Engineer. Selain itu } \\
\text { Operator pemotongan } \\
\text { harus lebih berhati-hati } \\
\text { dalam memotong pelat } \\
\text { wavy. Lakukan } \\
\text { pemeriksaan setiap ada } \\
\text { pelat < } 10 \mathrm{~mm} \text { minimal } 3 \\
\text { Mother Plate serta atur } \\
\text { settingan gap dengan } \\
\text { cepat \& tepat ketika } \\
\text { terdapat cacat max. } 3 \mathrm{x}\end{array}$ \\
\hline 7 & $\begin{array}{l}\text { Faktor } \\
\text { Metode }\end{array}$ & $\begin{array}{c}\text { SOP (Standard } \\
\text { Operating Procedure) } \\
\text { belum maksimal di } \\
\text { upgrade sehingga } \\
\text { ada beberapa } \\
\text { metode yang } \\
\text { seharusnya sudah di } \\
\text { ubah tapi belum } \\
\text { diubah. }\end{array}$ & $\begin{array}{l}\text { SOP belum } \\
\text { upgrade }\end{array}$ & $\begin{array}{c}\text { Tidak } \\
\text { adanya } \\
\text { pengawasan } \\
\text { dari atasan }\end{array}$ & $\begin{array}{c}\text { Mesin } \\
\text { Pemotongan }\end{array}$ & $\begin{array}{l}\text { Waktu } \\
\text { produksi }\end{array}$ & $\begin{array}{l}\text { Foreman, } \\
\text { supervisor, } \\
\text { engineer }\end{array}$ & $\begin{array}{l}\text { Beberapa point dalam } \\
\text { SOP harus sering di } \\
\text { upgrade terutama dalam } \\
\text { hal pemeriksaan fasilitas. } \\
\text { Karena banyak sekali } \\
\text { cacat yang muncul akibat } \\
\text { dari waktu pemeriksaan } \\
\text { fasilitas yang tidak } \\
\text { terjadwal }\end{array}$ \\
\hline
\end{tabular}

\section{Control}

Dalam penelitian ini, tahap control diserahkan kepada pihak perusahaan karena langkah improvement belum dapat diimplementasikan sehingga belum diketahui penekanan yang harus dilakukan untuk pengontrolan dan monitoring. Tahap control bertujuan untuk memastikan bahwa perbaikan tersebut dapat berlangsung secara terus menerus atau berkesinambungan dan tidak berjalan dalam waktu yang singkat saja. 


\section{KESIMPULAN}

Dari hasil penelitian yang telah dilakukan dapat diambil kesimpulan tingkat sigma dan nilai DPMO (Defect per Million Opportunities) dari produksi pelat pada tahun 2016 sebesar 3,47 dengan kemungkinan kerusakan sebesar 24.239 lembar untuk satu juta produksi dengan jenis kerusakan yang paling banyak terjadi adalah area shearing \& finishing dengan jumlah sebanyak 25.882 lembar. Setelah itu area mill sebanyak 12.326 lembar dan area steel making sebanyak 837 lembar. Kemudian setelah dilakukan analisa lebih jauh menggunakan diagram pareto didapati bahwa jenis cacat cutting fault \& transfer defect adalah yang paling banyak terjadi dengan prOsentase kerusakan $43 \%$. Usulan perbaikan yang dapat dilakukan diantaranya yaitu melakukan pembaharuan terhadap metodemetode dan SOP(standard operating procedure) yang sudah ada serta dilakukannya pengawasan terhadap kinerja operator dan pengembangan pengetahuan serta tak lupa untuk merencanakan penjadwalan maintenance (perawatan) yang baik sehingga masalah-masalah kecacatan dapat diminimalisir dan kualitas produk terjaga untuk mencapai zero defect dan kepuasan pelanggan.

\section{DAFTAR PUSTAKA}

Banuelas, R., Antony, J., \& Brace, M. (2005). An application of Six Sigma to reduce waste. Quality and Reliability Engineering International, 21(6), 553-570.

Breyfogle, F. W. (2003). Implementing six sigma: smarter solutions using statistical methods. John Wiley \& Sons.

Gaspersz, V. (2001). Total Quality Management, PT. Jakarta: Gramedia Pustaka Utama.

Ghanimata, F., \& Kamal, M. (2012). Analisis pengaruh harga, kualitas produk, dan lokasi terhadap keputusan pembelian (Studi pada Pembeli Produk Bandeng Juwana Elrina Semarang). Fakultas Ekonomika dan Bisnis.

Goh, T. N., Low, P. C., Tsui, K.-L., \& Xie, M. (2003). Impact of Six Sigma implementation on stock price performance. Total Quality Management \& Business Excellence, 14(7), 753-763.

Kumar, U. D., Nowicki, D., Ramírez-Márquez, J. E., \& Verma, D. (2008). On the optimal selection of process alternatives in a Six Sigma implementation. International Journal of Production Economics, 111(2), 456-467.

Pheng, L. S., \& Hui, M. S. (2004). Implementing and applying Six Sigma in construction. Journal of Construction Engineering and Management, 130(4), 482-489.

Ranjan Senapati, N. (2004). Six Sigma: myths and realities. International Journal of Quality \& Reliability Management, 21(6), 683-690.

Rohimudin, R., Dwiputra, G. A., \& Supriyadi, S. (2016). Analisis Defect pada Hasil Pengelasan Plate Konstruksi Baja dengan Metode Six Sigma. Jurnal INTECH Teknik Industri Universitas Serang Raya, 2(1), 110.

Trihendradi, C. (2006). Statistik SIx Sigma dengan Minitab: Panduan Cerdas Inisiatif Kualitas. Yogyakarta: CV. Andi Offset. 